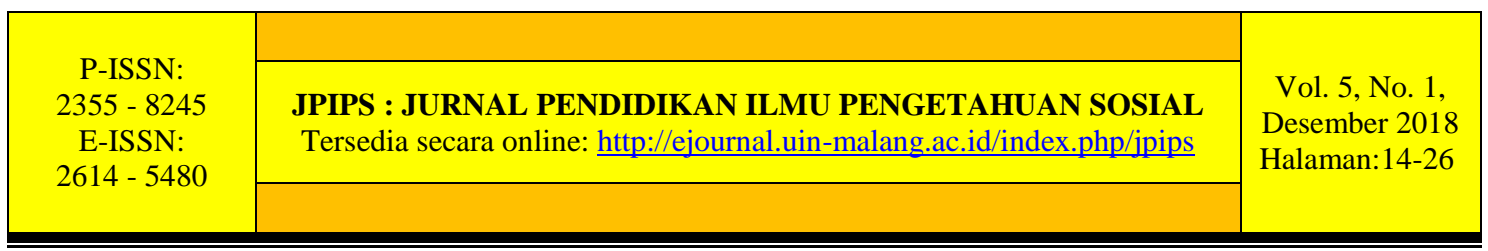

\title{
PERBEDAAN RELIGIUSITAS DAN MOTIVASI BERPRESTASI PADA MAHASISWA UNIVERSITAS ISLAM NEGERI UIN MAULANA MALIK IBRAHIM MALANG
}

\author{
Samsul Susilawati \\ UIN Maulana Malik Ibrahim Malang \\ susilawati@pips.uin-malang.ac.id
}

\begin{abstract}
Abstrak: Religiusitas adalah penghargaan keagamaan dan kedalaman kepercayaan yang diungkapkan melalui ibadah sehari-hari, doa, dan membaca ayat suci. Religiusitas dapat memberikan peran positif terhadap motivasi berprestasi bagi siswa. Pemahaman yang benar tentang agamanya dan praktik konstan keyakinan agamanya yang akan membedakan seseorang dari orang lain. Tanpa pemahaman yang benar dan praktik kepercayaan agamanya, suatu kebutuhan akan membentuk individu yang terampil, inisiatif, kepemimpinan, bertanggung jawab, jujur, disiplin, loyal, optimis, bersemangat dan toleran. Perspektif keagamaan dapat memainkan peran positif dalam kaitannya dengan prestasi yang akan dicapai siswa dalam menyelesaikan pendidikannya melalui pemahaman dan kepercayaan pada agamanya. Semakin tinggi tingkat agama seseorang, semakin mudah bagi mereka untuk menyelesaikan tugas dan tanggung jawab mereka dengan lebih baik dan berjuang untuk kesulitan dalam menghadapi nilai-nilai agama.
\end{abstract}

\section{Kata Kunci: religiusitas, prestasi motivasi}

Abstract: Religiosity is a religious appreciation and depth of trust expressed by daily worship, prayer, and reading of scripture. Religiosity can give a positive role to achievement motivation for the student. Correct understanding of his religion and the constant practice of his religious beliefs that will distinguish someone from others. Without a true understanding and practice of his religious beliefs, a necessity will form skilled individuals, initiative, leadership, responsible, honest, disciplined, loyal, optimistic, passionate and tolerant. Religious perspectives can play a positive role in relation to the achievement that the student will achieve in completing his education through understanding and belief in his religion. The higher the person's religious level the easier it will be for them to better complete their duties and responsibilities and to strive for difficulties in the face of religious values.

\section{Keywords: religiosity, achievement motivation}

\section{PENDAHULUAN}

Pembelajaran merupakan jantung dari proses pendidikan dalam suatu institusi Pendidikan. Kualitas pembelajaran bersifat kompleks dan dinamis, dapat dipandang dari berbagai persepsi dan sudut pandang melintasi garis waktu. Pada tingkat mikro, pencapaian kualitas pembelajaran merupakan tanggungjawab profesional seorang dosen atau Pendidik/dosen, misalnya melalui penciptaan pengalaman belajar yang bermakna bagi pebelajar dan fasilitas yang didapat pembelajar untuk mencapai hasil belajar yang maksimal. Pada tingkat makro, melalui model pembelajaran terpadu, lembaga pendidikan bertanggungjawab terhadap pembentukan tenaga pengajar yang berkualitas, 
yaitu yang dapat berkontribusi terhadap perkembangan intelektual, sikap, dan moral dari setiap individu pembelajar sebagai anggota masyarakat.

Secara instansial religius menunjuk pada sesuatu yang dirasakan sangat dalam yang bersentuhan dengan keinginan seseorang, yang butuh ketaatan dan memberikan imbalan sehingga mengikat seseorang dalam suatu masyarakat (Ahmadi, 1995). Mayer (dalam Nashori, 2002) mengatakan bahwa agama adalah seperangkat aturan dan kepercayaan yang pasti untuk membimbing manusia dalam tindakan terhadap Tuhan, orang lain, dan diri sendiri. Menurut (Anshari (1979) dalam Amri, 2012) walaupun istilah agama sering disamakan dengan istilah yang lain seperti religi (religion: bahasa Inggris) dan (ad-diin: bahasa arab), pada dasarnya semua istilah ini sama maknanya dalam terminologi dan teknis, meskipun masing-masing arti etimologis, riwayat, dan sejarah sendiri-sendiri. Anshari mendifinisikan agama, religi, ad-diin sebagai sistem keyakinan atas adanya yang mutlak di luar diri manusia dan suatu sistem peribadatan kepada sesuatu yang dianggap mutlak, yaitu Tuhan yang mempunyai kekuatan dan kekuasaan, serta sistem norma (kaidah) yang mengatur hubungan sesama manusia dengan manusia, dan dengan alam sekitarnya sesuai dan sejalan dengan keyakinan manusia itu sendiri (Anshari (1979) dalam Amri, 2012). Menurut Madjid (1997), religiusitas seseorang adalah tingkah laku manusia yang sepenuhnya dibentuk oleh kepercayaan kepada kegaiban atau alam gaib, yaitu kenyataan-kenyataan supra empiris. Manusia melakukan tindakan empiris sebagaimana layaknya, tetapi manusia yang memiliki religiusitas meletakan harga dan makna tindakan empirisnya di bawah supra empiris.

Dunia pendidikan, masalah motivasi selalu menjadi hal yang menarik perhatian. Hal ini dikarenakan motivasi dipandang sebagai salah satu faktor yang sangat dominan dalam ikut menentukan tercapai atau tidaknya tujuan pendidikan. Walaupun diakui bahwa kemampuan intelektual yang bersifat umum (inteligensi) dan kemampuan yang bersifat khusus (bakat) merupakan modal dasar utama dalam usaha mencapai prestasi pendidikan, namun keduanya tidak akan banyak berarti apabila siswa sebagai individu tidak memiliki motivasi untuk berprestasi sebaik-baiknya. Kemampuan intelektual yang tinggi hanya akan terbuang sia-sia apabila individu yang memilikinya tidak mempunyai keinginan untuk berbuat dan memanfaatkan keunggulannya itu. Atas dasar pemikiran di atas, peneliti memandang penting untuk melakukan penelitian terkait dengan Perbedaan religiusitas dan motivasi berprestasi mahasiswa Universitas Islam Negeri (UIN) Maulana Malik Ibrahim Malang.

Melihat latar belakang yang telah dikemukakan diatas, maka tujuan dilakukannya penelitian ini adalah memperoleh gambaran yang jelas tentang Ingin mengetahui tingkat religiusitas, motivasi belajar dan prestasi akademik dan Ingin mengetahui motivasi belajar dan prestasi akademik ditinjau asal sekolah mahasiswa UIN maulana malik Ibrahim malang ditinjau asal sekolah mahasiswa UIN maulana malik Ibrahim malang serta ingin mengetahui Apakah ada perbedaan tingkat religiusitas, motivasi belajar dan prestasi akademik mahasiswa UIN maulana malik Ibrahim malang.

\section{METODE}

Dalam rangka memperoleh pemahaman yang utuh mendalam dan menyeluruh terhadap fokus penelitian maka peneliti menggunakan paradigma interpretif dengan menggunakan metode kualitatif jenis studi kasus. Penelitian ini diharapkan dapat memahami fenomena atau gejala secara mendalam dan mendalami secara utuh 
perbedaan religiusitas dan motivasi berprestasi mahasiswa Universitas Islam Negeri (UIN) Maulana Malik Ibrahim Malang.

Tujuan utama penelitian kualitatif adalah untuk memahami (to understand) fenomena atau gejala sosial dengan lebih menitik beratkan pada gambaran yang lengkap tentang fenomena yang dikaji daripada memerinci menjadi variabel-variabel yang saling terkait dalam hal ini adalah perbedaan religiusitas dan motivasi berprestasi mahasiswa Universitas Islam Negeri (UIN) Maulana Malik Ibrahim Malang.

Analisis data dalam, penelitian ini akan dilakukan selama dan setelah proses pengumpulan data di lapangan. Data-data yang telah terkumpul ditulis secara utuh, ditranskrip, dikategorisasi, diberi kode, disimpan, dicari, dan diambil kembali untuk kepentingan pemaparan, triangulasi, analisis, dan integrasi data (Huberman \& Miles dalam Denzin \& Licoln, 1994).

\section{HASIL DAN PEMBAHASAN \\ Hasil}

\section{Perbedaan Religiusitas mahasiswa Universitas Islam Negeri (UIN) Maulana Malik Ibrahim Malang}

Univeritas/Sekolah merupakan sarana atau tempat pembelajaran bagi mahasiswa/siswa, yang mana banyak ilmu pengetahuan yang di ajarkan kepada peserta didik, dimana belum tentu di ajarkan di rumah mereka. Seperti, pengetahuan tentang agama, pengetahuan sosial, pengetahuan alam, pengetahuan bahasa, serta masih banyak lagi yang lainnya. Pada dasarnya setiap orang tua mengharapkan anak-anaknya dapat berprestasi di sekolah maupun luar sekolah, supaya menjadikan suatu kebanggaan tersendiri bagi orang tua, guru dan teman-temannya. Sering kali prestasi tersebut menjadi suatu perdebatan yang tidak pernah habis dibincangkan oleh setiap guru dan orang tua, prestasi sendiri terkadang membawa beban bagi seorang siswa yang di anggap mempunyai prestasi yang cukup baik namun tidak dalam motivasinya sendiri. Padahal dalam meraih prestasi diperlukan motivasi dalam belajarnya, yang menjadikan siswa tersebut mencapai hasil yang diinginkan, motivasi untuk berprestasi sendiri harus di dukung sepenuhnya oleh guru dan orang tua untuk pencapain prestasi yang terbaik.

Religiusiutas merupakan suatu bentukan dalam diri setiap insan manusia dalam meyakini TuhanNya. Setiap manusia memiliki rasa religi dalam dirinya untuk pengembangan diri menuju pencapaian yang hakiki. Motivasi berprestasi merupakan kekuatan penggerak yang meningkatkan vitalitas dalam diri setiap orang, yang berorientasi pada hasil yang terbaik atau prestasi itu sendiri. Sebagaimana penuturan Glock \& Stark yang menyatakan aktivitas keberagamaan bukan hanya terjadi ketika seseorang melakukan suatu ritual, tetapi juga dalam kehidupan lainnya. Ketika sadar (awareness) bahwa seseorang menyebut nama Tuhan, disana ada upaya bahwa setiap usaha yang dijalani untuk mencapai prestasi belajar akan mencapai hasil yang maksimal atau terbaik. Perilaku keberagamaan ini, tentunya tidak diperoleh dengan begitu saja, namun melalui sebuah proses pembelajaran yang panjang. Untuk menjawab ini ada dua pendekatan yaitu,. Pertama, ditelusuri melalui daftar pernyataan dari kuisioner. Kalau melihat dari daftar pernyataan kuisioner, kondisi ini bisa saja terjadi dan sangat mungkin terjadi. Karena dalam pernyataan tersebut hanya sebatas pada 
kegiatan-kegiatan ritual. Belum sampai pada internalisasi nilai dari kegiatan-kegiatan ritual tersebut. Bisa saja, melakukan sholat karena temannya sholat. Membayar zakat karena takut dibilang pelit. Melaksanakan haji karena saat ini sedang trend wisata ke tanah suci, dan lain sebagainya. Kedua, pendekatan teoritis.

\section{Perbedaan Motivasi dan hasil belajar Mahasiswa Universitas Islam Negeri Malang (UIN) Maulana Malik Ibrahim dalam Pembelajaran Pengembangan Materi IPS}

Motivasi berprestasi sebagai kekuatan penggerak yang mendorong individu untuk mencapai keberhasilan dalam bersaing dengan suatu ukuran keunggulan (standard of excellence), di mana ukuran keunggulan ini dapat berupa prestasinya sendiri sebelumnya (autonomus standard) atau dapat pula berupa prestasi orang lain (social comparisson standard). Dalam dunia pendidikan, masalah motivasi selalu menjadi hal yang menarik perhatian. Hal ini dikarenakan motivasi dipandang sebagai salah satu faktor yang sangat dominan dalam ikut menentukan tercapai atau tidaknya tujuan pendidikan. Walaupun diakui bahwa kemampuan intelektual yang bersifat umum (inteligensi) dan kemampuan yang bersifat khusus (bakat) merupakan modal dasar utama dalam usaha mencapai p restasi pendidikan, namun keduanya tidak akan banyak berarti apabila siswa sebagai individu tidak memiliki motivasi untuk berprestasi sebaikbaiknya. Kemampuan intelektual yang tinggi hanya akan terbuang sia-sia apabila individu yang memilikinya tidak mempunyai keinginan untuk berbuat dan memanfaatkan keunggulannya itu. Apalagi bila individu yang bersangkutan memang memiliki kemampuan yang tidak begitu menggembirakan, maka tanpa adanya motivasi sulitlah rasanya untuk mengharapkan sesuatu yang prestatif.

Dalam penjelasan mengenai masalah motivasi, kita selalu berpegang pada asumsi umum bahwa bila faktor-faktor lain yang mempengaruhi hasil belajar adalah sama, maka individu yang memiliki motivasi lebih tinggi akan mencapai hasil belajar yang lebih tinggi pula. Dalam dunia pendidikan, masalah motivasi selalu menjadi hal yang menarik perhatian. Hal ini dikarenakan motivasi dipandang sebagai salah satu faktor yang sangat dominan dalam ikut menentukan tercapai atau tidaknya tujuan pendidikan. Walaupun diakui bahwa kemampuan intelektual yang bersifat umum (inteligensi) dan kemampuan yang bersifat khusus (bakat) merupakan modal dasar utama dalam usaha mencapai prestasi pendidikan, namun keduanya tidak akan banyak berarti apabila siswa sebagai individu tidak memiliki motivasi untuk berprestasi sebaik-baiknya. Kemampuan intelektual yang tinggi hanya akan terbuang sia-sia apabila individu yang memilikinya tidak mempunyai keinginan untuk berbuat dan memanfaatkan keunggulannya itu. Apalagi bila individu yang bersangkutan memang memiliki kemampuan yang tidak begitu menggembirakan, maka tanpa adanya motivasi sulitlah rasanya untuk mengharapkan sesuatu yang prestatif. Dalam penjelasan mengenai masalah motivasi, kita selalu berpegang pada asumsi umum bahwa bila faktor-faktor lain yang mempengaruhi hasil belajar adalah sama, maka individu yang memiliki motivasi lebih tinggi akan mencapai hasil belajar yang lebih tinggi pula. Motif merupakan suatu keadaan, kebutuhan, atau dorongan yang disadari atau tidak disadari, yang membawa kepada terjadinya suatu perilaku. Sedangkan motivasi merupakan stimulasi atau rangsangan agar perilaku terjadi sesuai dengan arah yang dikehendaki. Motif merupakan suatu keadaan, kebutuhan, atau dorongan yang disadari atau tidak disadari, yang membawa kepada terjadinya suatu perilaku. Sedangkan motivasi merupakan stimulasi atau rangsangan agar perilaku terjadi sesuai dengan arah yang dikehendaki. Apa yang dimaksudkan dengan pemberian motivasi dalam belajar sebenarnya tidak lain 
daripada usaha yang dilakukan untuk membuat anak didik agar "mau" atau "berkeinginan" untuk belajar sesuai dengan keinginan pihak guru atau pihak orangtua. Usaha memberi motivasi ini dilakukan dengan memanipulasi situasi dalam diri individu (internal) maupun situasi di luar diri individu (external) secara psikologis. Kompleksitas reaksi individu terhadap berbagai perlakuan tentu saja akan menyulitkan usaha-usaha tersebut, akan tetapi dengan menggunakan tehnik motivasi yang terencana dengan baik dan tepat waktunya, maka usaha motivasi itu dapat dilakukan. Para ahli psikologi memberikan dasar-dasar teori motivasi dan teori psikologi belajar, tugas para pendidiklah untuk memadukan teori-teori tersebut dengan ilmu pendidikan yang dimilikinya dalam menciptakan situasi psikologis yang akan merangsang timbulnya motivasi dalam diri para siswa. Tidaklah layak untuk berharap bahwa teori motivasi akan memberikan "resep motivasi" yang siap pakai. Apa yang disumbangkan oleh teori merupakan dasar untuk memahami dinamika psikologi perilaku, sedangkan segi praktisnya akan sangat banyak tergantung pada keadan subjek dan situasi yang ada. Namun demikian, bukanlah berarti bahwa psikologi sama sekali tidak dapat memberikan pendekatan praktis terhadap masalah motivasi, hanya saja keberhasilan pendekatan itu akan banyak tergantung pada mereka yang menerapkannya secara langsung.

\section{Religiusitas dan motivasi berprestasi dalam Pembelajaran Pengembangan Materi IPS}

Religiusitas memberikan sumbangan yang cukup besar dalam membentuk Perilaku seseorang. Perilaku sendiri, tidak terlepas dari dua faktor penting yang mempengaruhinya, yaitu: pertama, faktor individual (seseorang) itu sendiri, semisal, masa kerja, usia, psikhis, fisik, jenis kelamin dan motivasi berperilaku. Kedua, situasional atau lingkungan luar, misalnya, suasana kerja, lingkungan kerja, dan lain sebagainya. Sedang keinginan berperilaku itu merupakan salah satu dari banyak keinginan manusia dalam berkehidupan. Keinginan-keinginan itu tidak bisa dilepaskan dari sifat manusia yang tidak pernah puas dan selalu ingin mendapatkan yang lebih dari apa yang telah didapatnya. Dan sudah barang tentu tiap orang memiliki penilaian dan perhatian yang berbeda terhadap perilaku mereka. Inilah yang secara psikologi dikatakan bahwa manusia memiliki struktur kepribadian. Selain itu, lingkungan juga ikut membentuk manusia dengan adanya interaksi dan internalisasi nilai-nilai. Dari interaksi dan internalisasi nilai-nilai ini manusia dapat berubah perilakunya, yang sudah barang tentu akan berimbas pada aktifitas kerjanya. Karena kuatnya pengaruh lingkungan ini, manusia perlu diarahkan perilakunya melalui lembagalembaga yang menanamkan pendidikan keberagamaan (religiusitas). Keberagamaan atau religiusitas diwujudkan dalam berbagai sisi kehidupan manusia. Aktivitas beragama bukan hanya terjadi ketika seseorang melakukan peribadatan (ritual), tapi juga ketika melakukan aktivitas lain yang di dorong oleh kekuatan supranatural. Bukan hanya yang berkaitan dengan aktivitas yang tampak dan dapat dilihat mata, tapi juga aktivitas yang tidak tampak dan terjadi dalam hati seseorang. Karena itu, keberagamaan seseorang akan meliputi berbagai macam sisi atau dimensi. Dengan demikian, agama adalah sebuah sistem yang berdimensi banyak. Agama adalah sistem simbol, sistem keyakinan, sistem nilai, dan sistem perilaku yang terlembagakan, yang semuanya itu berpusat pada 
persoalan-persoalan yang dihayati sebagai yang paling maknawi (ultimate meaning). Agama membentuk pribadi-pribadi yang kokoh dalam berperilaku, seperti, kejujuran, kedisiplinan, kesetiakawanan, keoptimisan, semangat, toleran. Karena pada dasarnya agama memang mengajarkan mengenai moral. Rasa keberagamaan seseorang (religiusitas) memiliki peran yang tidak kecil untuk memompa semangatnya dalam beraktifitas.

\section{Pembahasan}

\section{Perbedaan Religiusitas mahasiswa Universitas Islam Negeri (UIN) Maulana Malik Ibrahim Malang}

Sebagaimana dituliskan oleh Agustian (2001) bahwa manusia terdiri dari dua alam, yaitu alam sadar (fisik) dan alam bawah sadar (psikis). Pada wilayah fisik ini manusia hanya mampu menangkap apa yang dapat dilihat saja, dan hanya melakukan aktifitas untuk mengikuti keadaan lingkungannya. Namun pada wilayah psikis, erat hubungannya dengan mentalitas. Sehingga kalau ada fenomena, yaitu, orang rajin sembahyangnya kok perbuatannya malah melenceng dari yang digariskan oleh agama. Maka dari sini dapat diruntut, akar persoalannya. Mereka melakukan sholat hanya pada wilayah fisik saja atau sudah masuk ke dalam wilayah psikis. Oke mereka telah melakukan sholat, zakat, korban, haji dan kegiatan ritual lainnya. Tapi tidak hanya sebatas itu, masih ada satu wilayah lagi yang harus dilaksanakan yaitu, psikis. Dan wilayah psikis ini arahnya adalah spiritual. Selain itu, pengetahuan tentang keagamaan terkadang masih berada pada tataran mengetahui. Hal ini juga kalau dilihat dari pernyataan yang ada, hanya sebatas mengetahui tanpa ada kewajiban untuk mengimplementasikan pengetahuan itu dalam kehidupan sehari-hari. Jika, ajaran-ajaran agama hanya sebatas untuk diketahui, tanpa ada tanggung jawab moral terhadap terlaksananya ajaran tersebut di masyarakat, maka jangan heran kalau hikmah ulama akan menjadi kenyataan "islam dihancurkan oleh orang Islam sendiri" (al-islam mahjubun lil-muslim). Karena orang Islam hanya tahu apa itu zakat, al-qur'an, sejarah nabi, hanya kenal siapa itu Muhammad, dan lain sebagainya, tanpa mau meneladaninya.

\section{Perbedaan Motivasi dan hasil belajar Mahasiswa Universitas Islam Negeri Malang (UIN) Maulana Malik Ibrahim dalam Pembelajaran Pengembangan Materi IPS}

Teori-teori motivasi mencakup berbagai pandangan dan pendekatan. Diantaranya ada yang mendasarkan pada pandangan behaviorisme yang mengatakan bahwa manipulasi perilaku dapat dilakukan melalui teknk modifikasi perilaku yang berintikan pada pemberian penguatan positif dan penguatan negatif. Juga terdapat teori kognitif yang dalam masalah motivasi mendasarkan pada penciptaan situasi ketidakseimbangan dalam diri subjek. Dalam uraian berikut ini akan dikemukakan salah satu pendekatan yang mendasarkan pada teori kebutuhan (need theory).

Asumsi dalam pendekatan dengan teori kebutuhan adalah :

1. Semua perilaku tentu mempunyai sebab, untuk memahami perilaku siswa perlu lebih dahulu memahami sebabnya.

2. Untuk memberikan motivasi yang berhasil dalam belajar haruslah berawal dari pemenuhan kebutuhan dasar para siswa.

Konsep-konsep mengenai Kebutuhan Salah satu teori motivasi yang berangkat dari pendekatan kebutuhan (needs) individu adalah teori kebutuhan yang dikemukakan oleh Abraham Maslow dalam bukunya "Motivation and Personality". Maslow 
menyusun konsep kebutuhan manusia yang menjadi motif perilaku ke dalam beberapa tingkatan. Berdasarkan berbagai percobaan dan pengalamannya di bidang klinis, Maslow menyimpulkan bahwa perilaku manusia ditentukan dorongan dan arahnya oleh lima tingkatan kebutuhan, dari kebutuhan yang paling mendasar sampai kepada kebutuhan yang paling tinggi. Apabila kebutuhan yang paling dasar telah dirasakan terpenuhi oleh orang yang bersangkutan, maka kebutuhan tingkat berikutnya segera menjadi perhatian dan menjadi dominan dalam memotivasi perilaku selanjutnya. Setiap perilaku pada dasarnya dilandasi oleh hasrat pemenuhan kebutuhan yang dirasakan dalam tingkat yang berbeda-beda.

Secara ringkas, konsep Maslow mengenai kebutuhan tersebut disajikan berikut ini langsung dalam konteks psikologi belajar. Kebutuhan Fisiologis

Kebutuhan fisiologis merupakan kebutuhan yang bersifat darurat dan jarang terjadi. Apa yang menjadi kebutuhan disini adalah hal-hal yang dapat memuaskan secara biologis seperti makanan, air, oksigen, istirahat, aktivitas dan lain sebagainya.

Kebutuhan akan rasa aman, Bila seseorang merasa bahwa kebutuhan fisiologisnya relatif telah terpenuhi, maka perilakunya akan mulai berorientasi pada motif mencari rasa aman. Pada anak-anak yang dibesarkan tanpa pemenuhan rasa aman dari orangtua dan keluarganya, hal tersebut tampak jelas pada perilakunya yang didominasi oleh kehausan akan rasa aman, dalam bentuk takut berbuat salah dan takut mencoba dikarenakan kesalahan dapat berarti terancamnya rasa aman dirinya. Rasa aman keluarga datang dari sikap keluarga yang berdisiplin baik dan konsisten.

Dalam kelas, siswa sangat menghargai keteraturan. Dengan keteraturan siswa merasakan adanya kepastian mengenai apa yang boleh dan apa yang tidak boleh dilakukannya. Ketidakpastian akan menimbulkan keraguan dan ketakutan berbuat salah yang tidak akan mendukung proses belajar. Untuk memenuhi kebutuhan akan rasa aman ini, guru harus bersikap dan bertindak konsisten. Disiplin yang baik dan tidak kaku harus diterapkan karena tujuan disiplin adalah menolong siswa agar menjadi individu yang independen, mandiri dan dapat menentukan perannya sendiri. Bila disiplin lemah, kebutuhan akan rasa aman tidak terpenuhi, maka akan sia-sialah berbicara mengenai motivasi dalam belajar. Suatu disiplin harus ditegakkan berdasarkan aturan yang masuk akal dan kooperatif, tidak otoriter.

Kebutuhan akan Kasih Sayang dan Rasa, Serta Bila individu merasakan bahwa kebutuhan rasa amannya telah tercapai, maka segera akan timbul kebutuhan untuk memberi dan menerima afeksi kasih sayang. Bila kebutuhan akan kasih sayang tidak terpenuhi, maka individu akan merasa tidak mempunyai rasa serta sebagai anggota kelompoknya. Dalam situasi demikian, siswa akan menampakkan perilaku yang tidak disukai oleh orang lain, dan akibatnya orang lain akan mengimbangi dengan sikap yang serupa terhadap dirinya. Dengan demikian terjadilah keadaan yang merusak keinginan siswa untuk belajar dan untuk mencapai prestasi tertentu. Siswa yang tidak disukai oleh gurunya dan siswa yang tidak menyukai gurunya tidak akan memperoleh hasil belajar yang baik.

Kebutuhan akan Harga Diri Menurut Maslow, kebutuhan akan harga diri, kebutuhan akan evaluasi diri yang mantap, dapat dipenuhi oleh adanya kepercayaan diri dan kemandirian dalam diri individu serta oleh pengakuan, perhatian dan penghargaan diri oleh orang lain. Guna membentuk rasa harga diri yang tinggi dalam diri siswa, guru haruslah dapat menemukan sesuatu yang mampu dilakukan oleh siswa sehingga dapat membuatnya merasa penting. Dalam memberikan perasaan penting dan rasa diakui ini guru perlu memperhatikan perbedaan individual dalam berbagai aspek, seperti 
perbedaan status ekonomi sosial, status kemampuan intelektual, dan sebagainya. Sebagai contoh, pada siswa yang berasal dari keluarga dengan status ekonomi sosial yang rendah, angka rapor cenderung tidak mereka anggap penting dikarenakan mereka terbiasa dan dapat hidup dengan pendidikan yang terbatas. Karena itu, filsafat hidup mereka yang berorientasi pada nilai-nilai praktis harus diperhatikan apabila kita ingin memberikan motivasi. Bagaimana cara individu memandang status dan konsepnya mengenai harga diri, mereka akan menghendaki pendekatan motivasi yang berbedabeda.

Kebutuhan akan Aktualisasi Diri, Aktualisasi diri sebagai tingkat kebutuhan yang tertinggi menurut konsepsi Maslow, merupakan pencapaian apa yang memang mampu dicapai oleh seseorang. Seseorang yang belum dapat mencapai prestasi tertinggi sesuai dengan kemampuannya belum akan merasakan perlu untuk berusaha mencapai prestasi tersebut apabila kebutuhan tingkat di bawah aktualisasi diri belum terpuaskan. Timbulnya kebutuhan untuk melakukan apa yang dapat dilakukannya sebagai aktualisasi diri pribadinya secara utuh hanya akan terjadi bila individu merasakan bahwa kebutuhan fisiologisnya terpenuhi, kebutuhan akan rasa aman dan kasih sayang tercapai, serta kebutuhan harga dirinya terpuaskan. Apabila tidak, maka individu akan cenderung untuk mengarahkan perilakunya ke tujuan-tujuan pemuasan kebutuhan tersebut.

Rasa butuh untuk aktualisasi diri dapat dijadikan landasan dalam memberikan motivasi bila sejak awal siswa mulai diajar menentukan pilihan dan mengambil keputusan sendiri. Suatu tujuan yang dipilih dan ditetapkan sendiri akan mengandung unsur motivasi yang lebih kuat daripada tujuan yang ditetapkan oleh orang lain. Apabila tujuan terlalu banyak ditentukan oleh orang lain, maka seringkali tujuan itu tidak sesuai dengan kemampuan siswa. Mungkin terlalu rendah sehingga terlalu mudah dicapai, mungkin terlalu tinggi sehingga tidak mungkin dapat dicapai. Yang manapun, akan mengakibatkan tidak terpuaskannya kebutuhan aktualisasi diri siswa yang bersangkutan dan menjadikannya tidak berusaha dan tidak berkeinginan untuk mencapai tujuan tersebut.

Tehnik Motivasi menurut Teori Kebutuhan, Dalam teori kebutuhan dikatakan bahwa setiap individu selalu merasakan adanya suatu kebutuhan yang ingin dicapainya. Tidak ada orang yang sama sekali tiak merasakan adanya tuntutan kebutuhan, karena bila individu tidak merasakan kebutuhan sama sekali maka ia akan berada dalam keadaan diam total sebab ia tidak termotivasi untuk berbuat sesuatu. Keadaan seperti itu tidak pernah dialami oleh manusia. Dalam uraian berikut ditunjukkan beberapa pendekatan atau beberapa hal yang menjadi pokok dalam tehnik pemberian motivasi siswa untuk belajar, dengan memanfaatkan pemahaman mengenai kebutuhan individu seperti diuraikan diatas disertai oleh pemahaman akan perbedaan individual yang menjadi pertimbangan yang penting pula.

Ganjaran (Rewards) Pemberian ganjaran atau hadiah berkaitan dengan kebutuhan akan harga diri siswa. Bentuk ganjaran yang diberikan dapat bersifat simbolik seperti sertifikat, dapat berupa materi seperti buku, dan dapat pula bersifat psikologis seperti pujian dan pengakuan. Pada umumnya ganjaran materi akan lebih efektif bila diberikan pada siswa tingkat rendah sedangkan ganjaran untuk tingkat yang lebih atas harus lebih berbentuk simbolik dan psikologis. Pujian sebagai ganjaran merupakan insentif yang tidak dapat diabaikan perannya dalam meningkatkan motivasi agar mengulang perbuatannya yang dipuji itu. Pujian tidak harus dinyatakan secara verbal. Suatu anggukan kepala, senyum, dan bahkan perhatian yang tulus terhadap hasil 
kerja siswa bernilai sama dengan pujian langsung dan meningkatkan harga diri siswa karena ia dapat merasakan kepuasan sebagai orang yang berhasil dan mendapat pengakuan. Menurut para ahli, ganjaran yang bersifat positif seperti pujian akan memberikan efek yang positif, sedangkan ganjaran negatif seperti hukuman akan merusakkan harga diri dan efeknya akan menurunkan harga diri siswa. Hukuman hanya mungkin efektif dalam memotivasi siswa bila siswa masih dalam tahap kebutuhan mencari rasa aman, sehingga perilakunya didominasi oleh hasrat menghindari hukuman.

Nilai Prestasi, Nilai prestasi yang diberikan sebagai hasil THB, EBTA, dan untuk hasil pekerjaan rumah maupun tugas-tugas di sekolah, akan memiliki nilai motivasi yang tinggi apabila diberikan dengan cara yang tepat.

Terutama dalam memberikan nilai terhadap tugas-tugas sekolah sehari-hari, hendaklah dilakukan berdasarkan kemajuan belajar siswa masing-masing, tidak berdasarkan perbandingan dengan prestasi kelompok. Seorang siswa yang memperoleh peningkatan prestasi, yaitu dapat menyelesaikan tugasnya lebih baik Walaupun dalam kelas masalah ini biasanya kurang mendapat perhatian karena dianggap kurang penting bila dibandingkan dengan masalah kemampuan intelektual, namun sebenarnya harus disadari bahwa efektivitas dan efisiensi intelektual hanya dapat dicapai apabila faktor fisiologis pada diri siswa berada dalam kondisi normal. Sebagai contoh, seseorang tidak akan dapat berpikir dengan baik bila sedang berada dalam keadaan lapar (butuh makan) atau berada dalam keadan letih (butuh istirahat). Dalam keadaan-keadaan kebutuhan fisiologis seperti itu sedang dirasakan, maka perilaku seseorang akan banyak didominasi oleh hasrat untuk memuaskan kebutuhan tersebut. Dalam hal ini perlu memperhatikan kemampuan masing-masing siswa yang belum tentu sama. Jangan membuat perbandingan prestasi dengan teman-teman lainnya dikarenakan bila kemajuan siswa yang bersangkutan tidak cukup banyak, maka hal itu akan menanamkan rasa gagal dalam dirinya dan siswa tidak termotivasi untuk berusaha kembali.

\section{Religiusitas dan motivasi berprestasi dalam Pembelajaran Pengembangan Materi IPS}

Menurut Travers (2000) terdapat tujuh faktor yang dapat mempengaruhi motivasi seseorang untuk berprestasi, yaitu: (1). Kecemasan, (2). Sikap, (3). Rasa ingin tahu, (4). Kedudukan yang terkendali (locus of control), (5). Rasa tidak berdaya (learned helpessness),(6). Keyakinan diri terhadap kemampuan (self efficacy), (7). Belajar kooperatif (cooperative learning). Terkait dengan motivasi berprestasi ini, di dalam alQur'anul Karim Allah telah menganjurkan kaum muslimin untuk selalu berkompetisi dalam segala hal, yaitu dalam peningkatan ketakwaan, dalam mendekatkan diri kepada Allah dengan cara beribadah, dan beramal shalih (Najati, 2003, p.41 dalam Hasan, 2011).

Manusia religius yaitu manusia yang ber-Ketuhanan, yang memandang segala macam bentuk kehidupan adalah merupakan suatu kesatuan atau unity. Secara instinktif ataupun rasional segala pengalaman kehidupan baik yang positif maupun negatif selalu dihubungkan dengan keseluruhan nilai kehidupan, dan Tuhan merupakan prinsip obyektif sebagai pengalaman pribadi. Pada dasarnya bahwa manusia religius adalah manusia yang struktur mental keseluruhannya secara tetap diarahkan kepada pencipta nilai mutlak, memuaskan, dan tertinggi yaitu Tuhan. Glock \& Stark (Dister, 1982) mengartikan religiusitas sebagai keberagamaan, yang artinya adanya internalisasi agama itu di dalam diri seseorang. Religiusitas diwujudkan dalam berbagai sisi kehidupan manusia. Aktivitas keberagamaan bukan hanya terjadi ketika seseorang melakukan 
perilaku ritual (beribadah khusus) saja tetapi juga ketika melakukan aktivitas kehidupan lainnya. Bukan hanya berkaitan dengan aktivitas yang dapat dilihat mata, tetapi juga aktivitas yang tidak tampak dan terjadi dalam hati sanubari seseorang. Glock dan Stark (dalam Lindzey dan Aronson, 1975; Spilka, dkk, 1985) berpendapat bahwa religiusitas terdiri dari lima dimensi sebagai berikut:

1. Dimensi ideologi yaitu tingkatan sejauh mana seseorang menerima hal-hal yang dogmatik dalam agamanya.

Misalnya kepercayaan tentang sifat-sifat Tuhan, adanya malaikat, surga dan neraka.

2. Dimensi ritual yaitu tingkatan sejauh mana seseorang mengerjakan

kewajiban-kewajiban ritual dalam agamanya.

Misalnya sholat, puasa, mengaji, dan membayar zakat serta ibadah haji.

3. Dimensi pengalaman yaitu perasaan atau pengalaman keagamaan yang pernah dialami dan dirasakan.

Misalnya merasa dekat dengan Tuhan., merasa takut berbuat dosa atau merasa bahwa doadoanya dikabulkan Tuhan

4. Dimensi konsekuensi yaitu dimensi yang mengukur sejauh mana perilaku seseorang dimotivasi oleh ajaran agamanya di dalam kehidupan sosial.

Misalnya apakah ia mengunjungi tetangganya yang sedang sakit, menolong orang yang kesulitan dan mendermakan hartanya.

5. Dimensi intelektual yaitu seberapa jauh pengetahuan seseorang tentang ajaran agamanya, terutama yang ada dalam kitab suci.

Menurut Clark (2003) konflik dan keraguan beragama merupakan ciri kehidupan beragama pada masa remaja yang sangat menonjol. Remaja mulai mempertanyakan dengan sangat kritis tentang ajaran-ajaran agama yang diterima begitu saja pada masa kanak-kanak. Pergaulan remaja dengan teman sebaya dan masyarakat akan menyebabkan remaja mendapatkan informasi tentang keyakinan dari agama lain. Selajutnya Paulotzian menjelaskan bahwa konflik dan keraguan merupakan suatu yang wajar dalam proses perkembangan kehidupan beragama seseorang termasuk remaja. Remaja membutuhkan landasan pemahaman rasional yang kuat dalam kehidupan beragama. Hal ini dapat dicapai dengan mempertanyakan, mengevaluasi dan membandingkan ajaran agama yang satu dengan yang lain. Dari penelitian Kementrian Negara Kependudukan dan Lingkungan Hidup disebutkan bahwa religiusitas memiliki dimensi-dimensi Iman, Islam, Ihsan dan Amal (1987 Subandi, 1988, Adisubrata, 1992 dalam Rahayu, 2009). Kedua cara pembagian tersebut ternyata memiliki kesesuaian yaitu dimensi Iman sebagai religious beliefs, diemnsi Islam sebagai religious practice, dimensi ihsan sebagai religious feeling, dimensi ilmu sebagai religious knowledge dan dimensi Amal sebagai religious affect. Kelima dimensi tersebut merupakan cerminan religiusitas dan dapat digunakan sebagai dasar mengukur sejauh mana sifat religiusitas seseorang.

Dinamika perkembangan religiusitas seseorang dipengaruhi oleh beberapa faktor., baik faktor lingkungan maupun faktor perkembangan. Kehidupan beragama mengalami perkembangan dari fase kehidupan yang satu ke fase kehidupan yang lain. Para ahli psikologi agama mengacu pada teori perkembangan, teori yang sering dipakai sebagai dasar adalah teori perkembangan kognitif dari Piaget dan Erickson (Paloutzian, 1996).

Paloutzian selanjutnya mengemukakan bahwa dalam sejarah perkembangan psikologi terhadap perkembangan agama, ditambahkan bahwa kehidupan agama 
seseorang tidak mengalami banyak perubahan setelah dewasa. Diketauhi bahwa pada orang-orang yang dewasa awal keyakinan secara umum dan afiliasi agama tetap sama atau lebih sering menetap daripada yang berubah.

Sedangkan Thouless (1992) mengemukakan empat faktor yang mempengaruhi perkembangan religiusitas khususnya pada remaja, yaitu:

a. Pengaruh Pendidikan atau pengajaran dan berbagai tekanan sosial termasuk pendidikan dari orang tua, tradisi-tradisi sosial, tekanan lingkungan sosial yang disepakati oleh lingkungan itu.

b. Berbagai pengalaman yang membentuk sikap keagamaan, terutama pengalamanpengalaman mengenai keindahan, keselarasan dan kebaikan di dunia ini, (factor alami) konflik moral (factor moral) dan pengalaman emosi beragama.(factor afeksi)

c. Kebutuhan yang belum terpenuhi terutama kebutuhan keamanan, cinta kasih, harga diri serta adanya ancaman kematian.

d. Berbagai proses pemikiran verbal atau faktor intelektual.sebagai contoh masuknya atau beralihnya seseorang dari satu agama ke agama yang lain lantaran dia menemukan temuan ilmiah yang ada hubungannya dengan sesuatu yang ada dalam kitab-kitab suci.

Menurut Clark (2003) konflik dan keraguan beragama merupakan ciri kehidupan beragama pada masa remaja yang sangat menonjol. Remaja mulai mempertanyakan dengan sangat kritis tentang ajaran-ajaran agama yang diterima begitu saja pada masa kanak-kanak. Pergaulan remaja dengan teman sebaya dan masyarakat akan menyebabkan remaja mendapatkan informasi tentang keyakinan dari agama lain. Selajutnya Paulotzian menjelaskan bahwa konflik dan keraguan merupakan suatu yang wajar dalam proses perkembangan kehidupan beragama seseorang termasuk remaja. Remaja membutuhkan landasan pemahaman rasional yang kuat dalam kehidupan beragama. Hal ini dapat dicapai dengan mempertanyakan, mengevaluasi dan membandingkan ajaran agama yang satu dengan yang lain.

Secara teoritis akan sangat berbeda Prestasi Belajar seseorang antara orang yang tidak memiliki dasar agama yang kuat dan yang memiliki dasar agama yang telah tertempa melalui pengalaman dan pemahaman yang benar terhadap keyakinan agamanya. Pemahaman yang benar terhadap agamanya dan pengamalan yang secara terus menerus terhadap keyakinan agamanya yang akan membedakan seseorang dengan orang lain. Tanpa adanya pemahaman yang benar dan pengamalan atas keyakinan agamanya, sebuah keniscayaan akan membentuk pribadi-pribadi yang trampil, inisiatif, leadership, bertanggung jawab, jujur, disiplin, setia kawan, optimis, semangat dan toleran, dan lain-lain. Maka, betapa besar pengaruh religiusitas seseorang terhadap perilakunya serta prestasinya di masyarakat. Seorang yang selalu taat melakukan ritual keagamaannya, misalnya sholatnya khusyu', akan berimplikasi terhadap aktifitas kerjanya, salah satunya adalah disiplin. Memiliki keyakinan terhadap keberadaan sang maha pencipta, akan menumbuhkan sikap optimis dalam bekerja. Pengamalan yang benar akan ajaran-ajaran agamanya, akan menumbuhkan sikap kesetiakawanan, toleran, bertanggung jawab baik antar sesama teman maupun terhadap atasan. Keluasan pengetahuan agamanya, menumbuhkan sikap inisiatip dan leadership. Sedang pengalaman- pengalaman keagamaan, akan menumbuhkan sikap yang selalu menerima (qona'ah) terhadap apa yang telah diberikan oleh Tuhan kepadanya. Penelitian ini penting dilakukan untuk dapat membantu para mahasiswa/remaja dalam 
meningkatkan motif prestasi, menghayati makna hidupnya dan meningkatkan religiusitasnya.

\section{KESIMPULAN}

Kesimpulan dari penelinitian ini adalah sebagai berikut;

1. Religiusitas dapat memberikan peranan positif terhadap motivasi berprestasi bagi mahasiswa. Hal ini membuktikan bahwa perspektif agama dapat berperan positif berkaitan dengan prestasi yang hendak dicapai mahasiswa dalam menyelesaikan pendidikannya melalui pemahaman dan keyakinan terhadap agamanya.Semakin tinggi tingkat keberagamaan seseorang maka semakin mudah bagi mereka untuk menyelesaikan tugas dan tanggungjawab dengan lebih baik serta berusaha keras dalam menghadapi kesulitan dengan berlandaskan nilai-nilai agama. Di samping itu semakin tinggi motivasi mereka dalam menyelesaikan program pendidikan sehingga mencapai keberhasilan.

2. Peran Motivasi pada mahasiswa apabila ditingkatkan lebih tinggi, maka perasaan ingin sukses dapat terwujud, sehingga dapat mengatasi tugas-tugasdan tanggung jawab mereka dalam situasi tertekan apapun melalui keyakinan individu akan kemampuannya yang tinggi, untuk memobilisasi motivasi menuju kesuksesan.

3. Motivasi seseorang dalam mencapai keberhasilan akan terwujud apabila religiusitas (sikap keberagamaan) dan keyakinan akan kemampuan diri ditingkatkan secara bersama-sama. Hasil penelitian menunjukkan bahwa Perbedaan Religiusitas dan Motivasi berprestasi memberikan kontribusi terhadap prestasi belajar Pengembangan Materi IPS.

\section{DAFTAR PUSTAKA}

Agustian, Ary Ginanjar. (2001). Rahasia Sukses Membangun Kecerdasan Emosi dan Spiritual ESQ Berdasarkan 6 Rukun Iman dan 5 Rukun Islam. Jakarta: Arga. Ahmadi, Abu. (1995). Psikologi Umum. Jakarta: PT Rineka Cipta.

Amri, Kharisma Faundria. (2012). Analisis Faktor-Faktor yang Mempengaruhi Nasabah dalam Pemilihan KPR Syariah: Studi Kasus Bank Muamalat Indonesia, TBK. Skripsi. Universitas Indonesia, Indonesia.

Dister, N.S. (1982). Pengalaman dan Motivasi Beragama, Pengantar Psikologi Agama. Jakarta: Leppmas.

Madjid, R. (1997). Islam Kemoderenan dan Ke-Indonesiaan. Bandung: Mizan Pustaka.

Nashori, H. Fuad \& Mucharam, Rachmy Diana. (2002). Mengembangkan Kreativitas dalam Perspektif Psikologi Islam. Jogjakarta: Menara Kudus.

Huberman, A, Michael. \& Miles, Mattew B. (1994). .Data Management and Analysis Methods, dalam Handbook of Qualitative Research. Norman K. Denzin and Yvonna S. Lincoln, eds, pp 428-444. Thousand Oaks, CA : SAGE.

Paloutzian, R.F. (1996). Invitation to The Psychology of Religion. Second Edition. Allyn and Bacon. Boston.

Thouless. R.H. (1992). Pengantar Psikologi Agama (Terjemah: Machnum Husein). Jakarta: Rajawali Press.

Clark, R. C \& Mayer, R. E. (2003). E-Learning and The Science of Instruction. San

Lindzey, G dan Aronson, E. (Eds). (1975). The Handbook of Social Psychology. New Delhi: Addison-Westly Publising Company.

Hasan, Aliah.B.P. (2011). Hubungan Religiusitas dan Self Efficacy Terhadap Motivasi Berprestasi Pada MahasiswaWarga Binaan Lembaga Pemasyarakatan 
Cipinang Jakarta. 4 (2).

Rahayu, Iin Tri. (2009). Religiusitas dan Psychological Well-Being. Ulul Albab, 10 (2). 